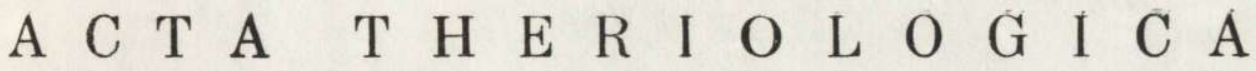 \\ VOL. XIV, 4: 35-47. \\ BIAŁOWIEŻA \\ 5.IV.1969
}

Elżbieta W O Ł K

\section{Body Weight and Daily Food Intake in Captive Shrews}

[With 4 Tables \& 4 Figs.]

\begin{abstract}
During the period from November 1966 to October 1967 studies were made of the seasonal variations in body weight and absolute (expressed in grammes) and relative (in percentages of body weight) food intake in 36 shrews (Sorex araneus L in n e u s, 1758) kept in cages in the open air and fed ad libitum. The phenomenon of seasonal variations in body weight was observed, although in a less distinct form than under natural conditions. Weight loss during the period from August-October to January-February was $16.7 \%$, while the spring jump in growth during the period from January-February to May-June was expressed by increase in body weight of $37.2 \%$. In young shrews food intake varied from $50.7 \%$ of body weight in November to $62.1 \%$ from December to February; in old adults from $44.6 \%$ from May to August to $76.9 \%$ in March. Absolute daily food intake during the winter period is only $9.7 \%$ higher than in summer. The amount of food eaten by shrews during a period of 24-hours depends in reverse proportion on the surrounding temperature. This relation is proper to the mean values of the 10-day periods taken into consideration over the course of the years, but does not occur when variations from day to day are considered. The caloric value of meat eaten by shrews during a 24-hour period was on an average from $15.71 \mathrm{kcal}$ in November to $22.56 \mathrm{kcal}$ in March, that is, from $1.89-3.45 \mathrm{kcal} / \mathrm{g}$ of the shrew's body.
\end{abstract}

\section{INTRODUCTION}

The phenomenon of seasonal variations in the shrew, known as Dehnel's phenomenon, has been elaborated by many authors. The majority of the studies (for a detailed list of references see $\mathrm{Pucek}$, 1965) refer to the morphological variation in shrews under natural conditions. Pucek (1964) examined this question in relation to shrews kept in a laboratory.

The object of the studies made was to ascertain what course is taken by seasonal variations in body weight and food intake under habitat conditions closer to natural ones, that is, in cages kept out of doors and when the animals were supplied with food ad libitum. This was intended to reveal how great the increase is in the food requirements of shrews under winter conditions. Examination was also made of the connections between the amount of food consumed and body weight and also the temperature of the animals' surroundings. 


\section{MATERIAL AND METHOD}

The investigations were carried out over a whole year, during the period from November 14th 1966 to October 20th 1967. The experiment included 36 shrews, 1045 observations of which were made in respect of body weight and daily food intake. The animals were caught in the Białowieża National Park. Data on the length of life of different animals during the experiment and the numbers in the groups examined in successive months are given in Table 1. Some of the

Table 1.

Length of life of different animals in the experiment and number of animals examined in successive months.

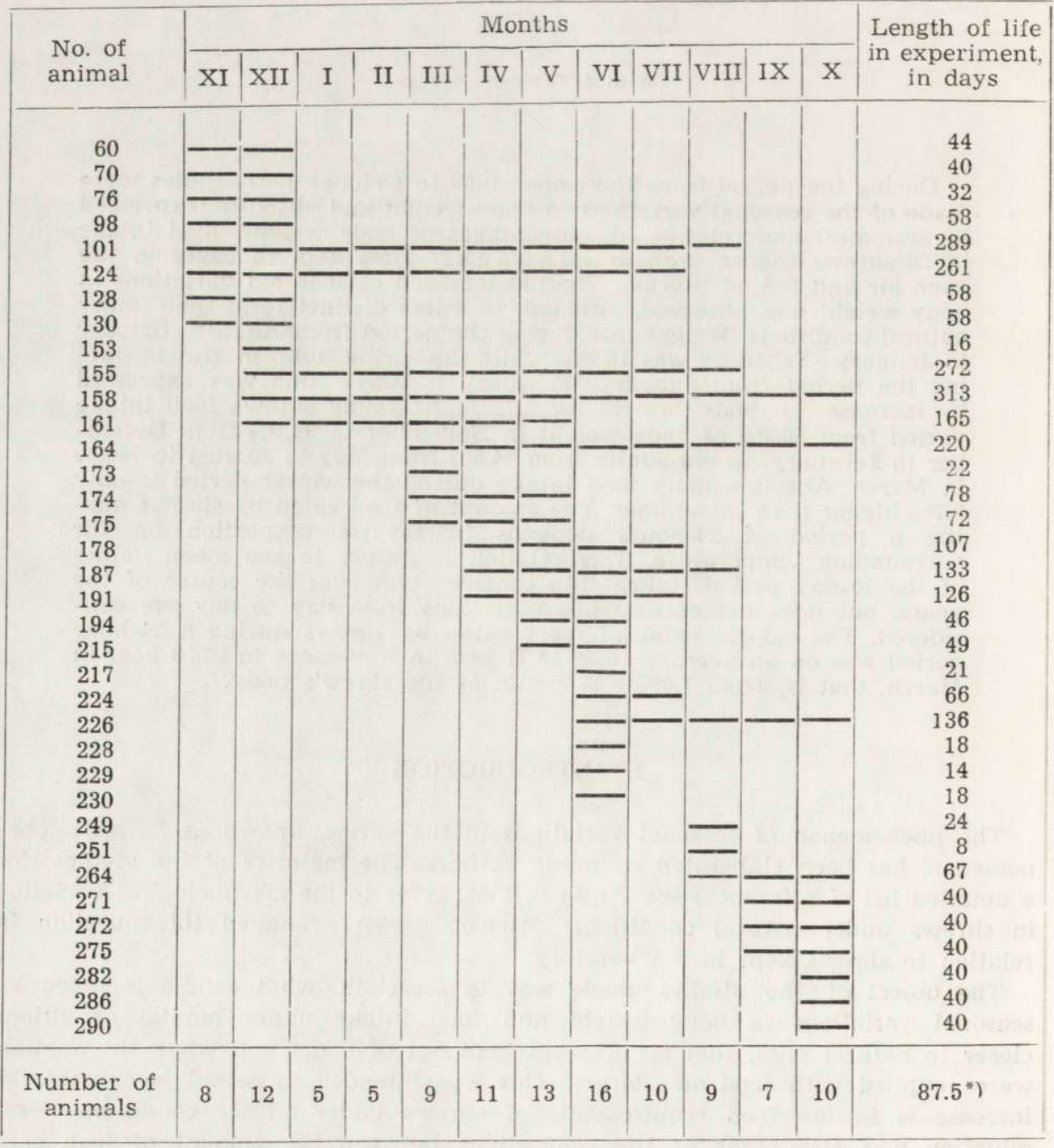

* Mean length of life. 
shrews took part in the experiment during the first calendar year of life as young animals, and in the second year as old adults. The animals were divided into young and old adults on the basis of the appearance of the coat and degree of wear of the teeth ( $\mathrm{Dehne} 1,1949$ ). As the animals died their number was replenished by individuals from among those kept in the laboratory, allowing a period of adaptation to the experimental conditions of at least ten days, or using animals freshly caught in the area.

The experimental animals were kept out of doors in individual wooden cages measuring $15 \times 30 \times 42 \mathrm{~cm}$. Sets of cages were placed in a wooden container with a glass front. When the temperature fell below $0^{\circ} \mathrm{C}$ the container was covered with straw mats, but even so it proved impossible to maintain the air temperature inside the containers at nearly $0^{\circ} \mathrm{C}$, that is, the temperature prevailing in the forest litter under the snow ( $\mathrm{C}$ oulianos \& $\mathrm{J}$ o hnels, 1962). According to $\mathrm{J}$ u din (1962) the snow cover makes it possible for a temperature several degrees below $0^{\circ} \mathrm{C}$ to be maintained at a depth of $55 \mathrm{~cm}$ when the air temperature is from -14 to $-21^{\circ} \mathrm{C}$. Air temperature in the container varied over the year from -16 to $+35^{\circ} \mathrm{C}$; in winter the mean minimum temperature in the container was several degrees lower than in the soil at a depth of $5 \mathrm{~cm}$ (Table 2).

Table 2.

Mean air temperature in container and soil temperature (in ${ }^{\circ} \mathrm{C}$ ).

\begin{tabular}{|c|c|c|}
\hline Period & $\begin{array}{l}\text { Temperature of soil } \\
\text { at depth of } 5 \mathrm{~cm}\end{array}$ & $\begin{array}{c}\text { Minimum temperature } \\
\text { of air }\end{array}$ \\
\hline $\begin{array}{ccc}10-19 & \text { XII } & 1966 \\
10-19 & \text { I } & 1967 \\
10-19 & \text { II } & 1967\end{array}$ & $\begin{array}{l}-0.6 \\
-0.4 \\
-0.7\end{array}$ & $\begin{array}{l}-2.1 \\
-7.7 \\
-5.1\end{array}$ \\
\hline
\end{tabular}

In the middle 10-day period of each month the shrews were weighed for 10 or 11 days, given a weighed amount of food. and the remains of food left from the previous day enable to determine the amount of food consumed during 24 hours. During the periods between these experimental cycles the animals were weighed every second or third day. Their food consisted of a mixture of minced beef liver, heart, kidneys and spleen. The minced meat was partly dried at a temperature of $70^{\circ}$ after spreading a layer $0.5 \mathrm{~cm}$ thick on medical gauze. Before feeding the animals the food was cut, together with the gauze, into squares about $5 \times 5 \mathrm{~cm}$. These operations were carried out in order to make it impossible for part of the food to be dragged round the cage, and to facilitate collection of the remains. A trial portion was placed daily in the container in order to calculate the weight losses due to the meat drying up, and the necessary correction made to the value of the food eaten by the given animal. During the periods separating experimental cycles larvae of Tenebrio molitor L. and germinating wheat were added to the meat.

\section{VARIATIONS IN BODY WEIGHT}

Data given in Table 3 show that the average body weight of shrews decreased from summer to winter by $1.18 \mathrm{~g}$, that a gradual increase begins as from March, and attainment of maximum values (average 
$9.5 \mathrm{~g})$ took place during the period from May to August. The course taken by the curve of seasonal variations in body weight (Fig. 1A) is in agreement with the curve for free-living shrews ( $\mathrm{Pucek}, 1965)$, but is far more even and does not attain extreme values (Fig. 2). Comparison of the mean body weight of the experimental shrews with that of free-living shrews and those kept in the laboratory (Table 3) shows that the weight of the experimental shrews is intermediate between the body weight of free-living and laboratory shrews in the case of young animals in the winter and old adults during the period from May

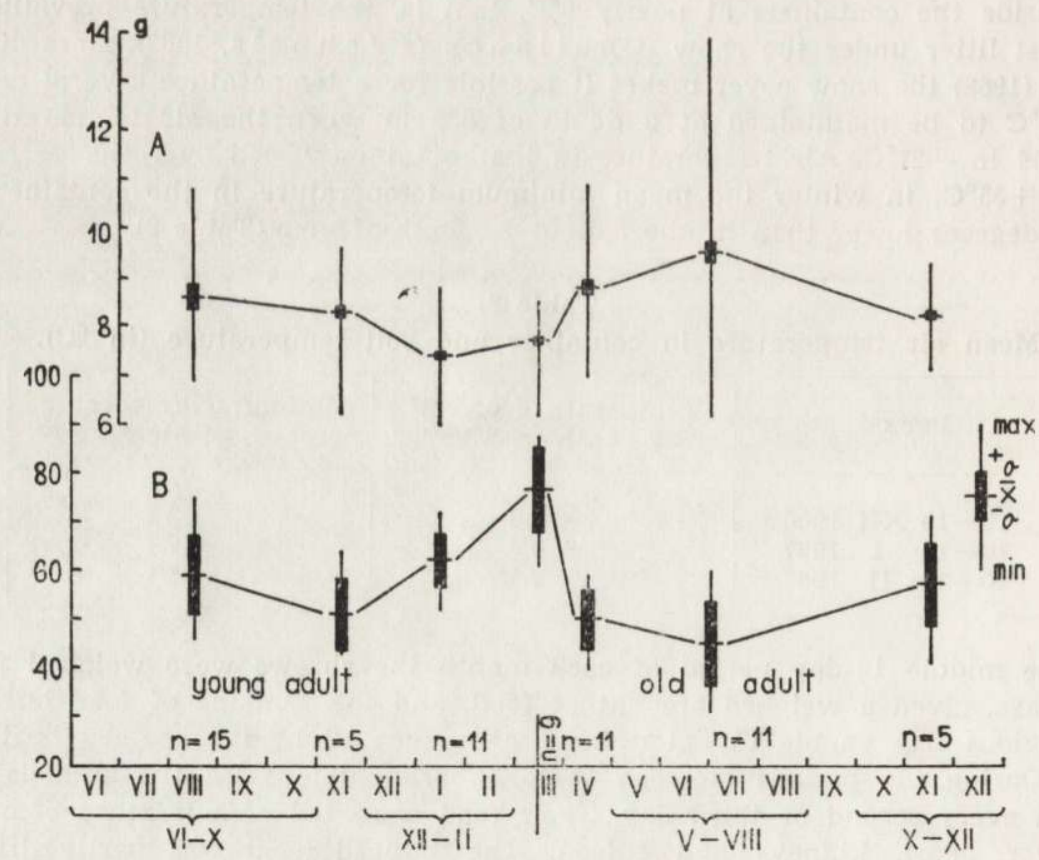

Fig. 1. Seasonal-age variations in body weight (in grammes - A) and relative daily food intake (in percentages of body weight - B) in shrews during the experiment.

to June. In contradistinction to animals kept under laboratory conditions, the experimental shrews exhibit a winter depression and spring jump in growth, although to a slighter degree than free-living animals. Weight loss during the period from August - October to January February was $16.7 \%$ in experimental animals, while in free-living animals this value was $24.4 \%$. The difference in growth during the spring period is far greater: $37.2 \%$ in experimental animals as compared with $91.2 \%$ in free-living shrews. This difference is certainly influenced by the lack of pregnant and nursing females under laboratory conditions. Weight loss in experimental shrews during the period 


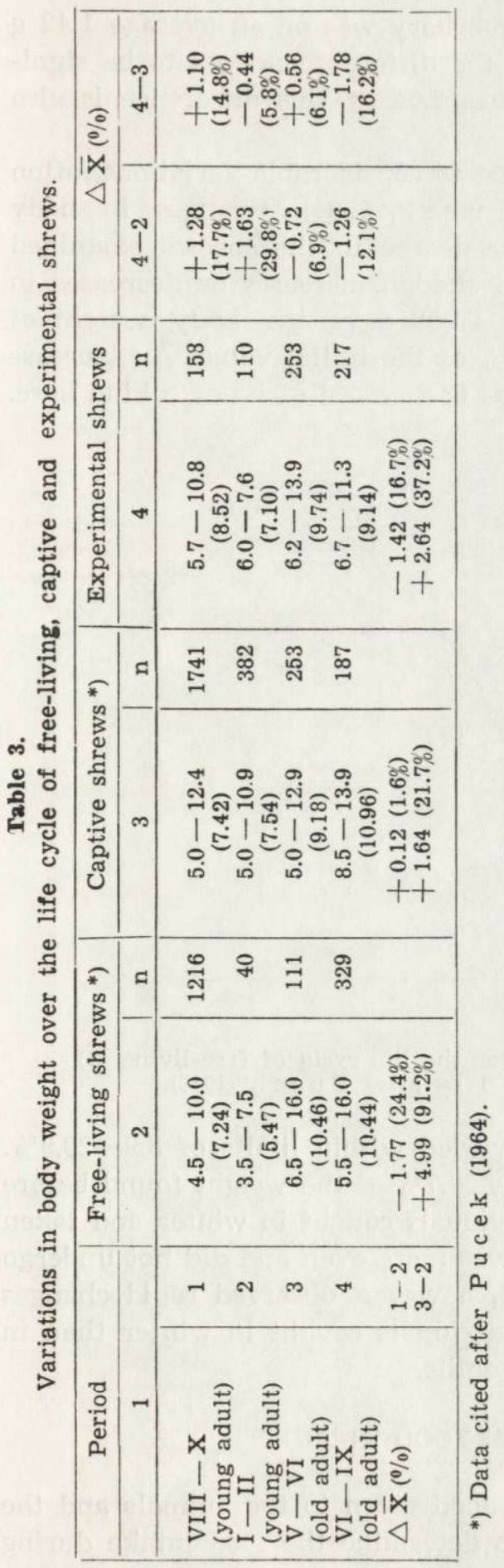

\begin{tabular}{|c|c|c|}
\hline $\begin{array}{l}E \\
\dot{x} \\
1 \\
x\end{array}$ & 空 & ம \\
\hline $\begin{array}{l}\overrightarrow{3} \\
\\
1 \\
>\end{array}$ & 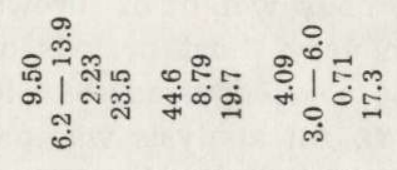 & ఇర్లే \\
\hline$\geq$ & 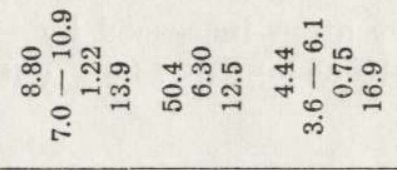 & $=\vec{\Xi}$ \\
\hline$\Xi$ & 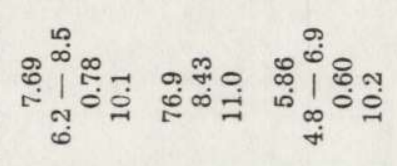 & $\infty \approx$ \\
\hline $\begin{array}{c}\exists \\
1 \\
\exists\end{array}$ & 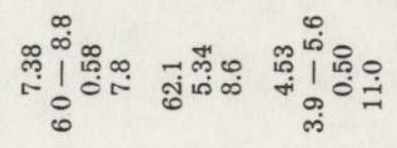 & = స్ \\
\hline$\vec{x}$ & 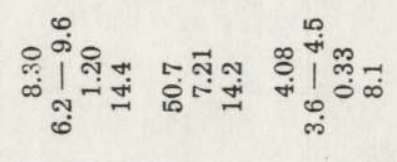 & 108 \\
\hline $\begin{array}{l}x \\
1 \\
5\end{array}$ & 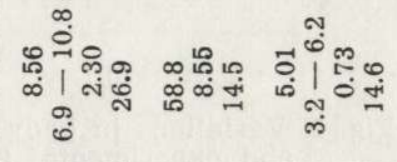 & ๑ே \\
\hline & $\left.\left|x \frac{n \cdot}{0} \cdot n\right\rangle|x| x\right\rangle\left|x \frac{\pi}{0} \cdot n\right\rangle$ & \\
\hline 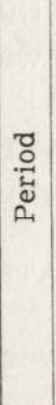 & 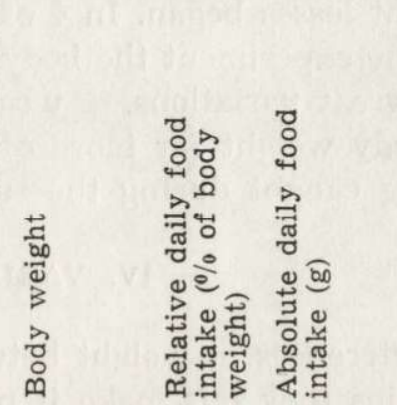 & 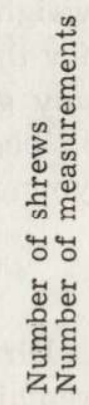 \\
\hline
\end{tabular}


from August-October to January-February was on an average $1.42 \mathrm{~g}$ (when checked by the $t$ Student test the difference proved to be significant). Weight increase in spring was $2.64 \mathrm{~g}$; this difference is also statistically significant.

The body weight of shrews is subject to considerable variations, often within very short periods of time ( $\mathrm{Pucek}, 1964)$. Changes in body weight also occurred, but to a lesser degree in the shrews examined (Fig. 3). An analysis was made of 55 sudden increases or decreases in body weight exceeding $1 \mathrm{~g}$. Within 4-20 days the body weight of shrews often increased by $12.5-43.6 \%$ of the initial value. An increase in body weight of $34.4 \%$ within 4 days is a record of its own kind here.

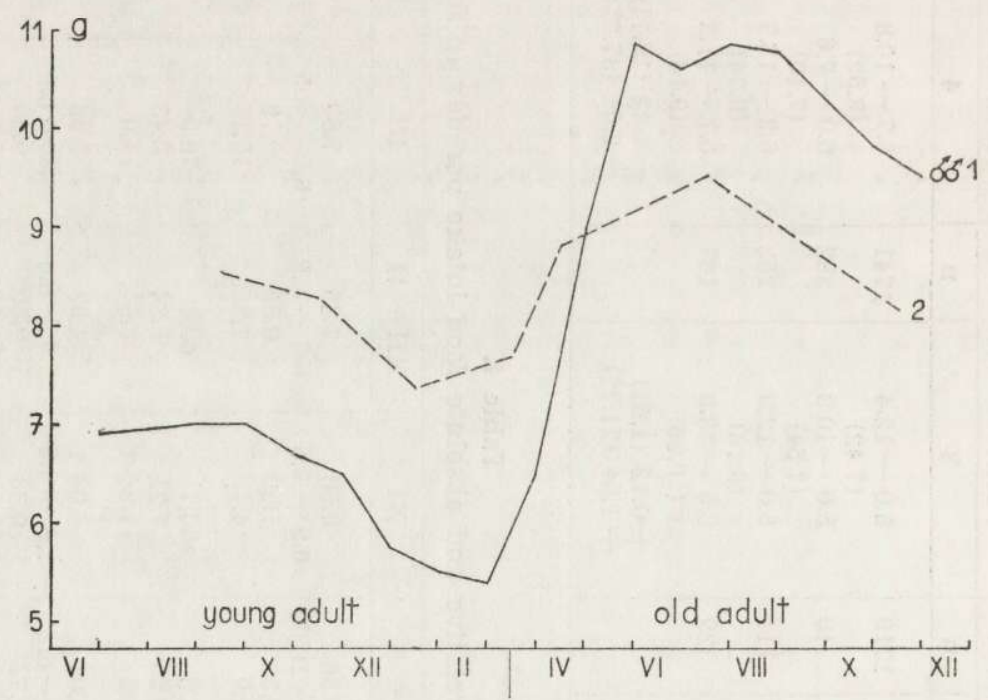

Fig. 2. Variations in body weight over the life cycle of free-living (1) and experimental (2) shrews. 1 - after P u cek (1965).

Weight decrease within $2-15$ days varied within limits of $8.9-29.9 \%$. Maximum decrease within 2 days was $20.7 \%$ of the weight found before weight losses began. In 4 of the individuals caught in winter and taken for the experiment the body weight was more even and did not undergo any great variations. P u cek (1964), however, observed rapid changes in body weight far more often in individuals caught in winter than in young caught during the summer months.

\section{VARIATIONS IN FOOD INTAKE}

Differences in weight between the food given to the animals and the remains they left make it possible to determine the food intake during 


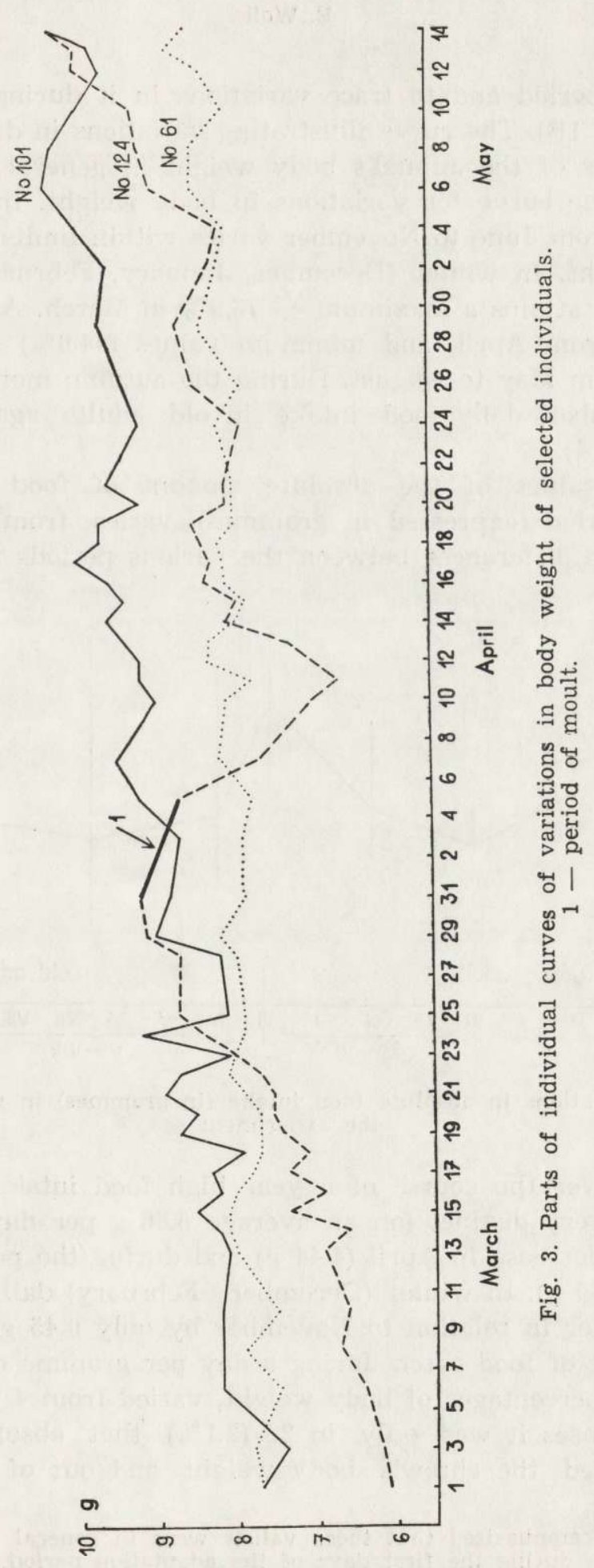


the 24-hour period and to trace variations in it during the course of the year (Fig. 1B). The curve illustrating variations in daily food intake in percentages of the animal's body weight in general takes a course contrary to the curve for variations in body weight. In young shrews food intake from June to November varies within limits of $58.8-50.7 \%$ of body weight. In winter (December, January, February) it increases to $62.1 \%$, and attains a maximum $-76.9 \%$ in March. A sharp decrease takes place from April, and minimum values (44.6\%) are attained in old adults from May to August. During the autumn months from October to December, daily food intake in old adults again increases to $57.3 \%$ (Table 4).

The mean values of the absolute amount of food consumed over a 24-hour period (expressed in grammes) varies from 4.08 to $5.86 \mathrm{~g}$ (Table 4). The differences between the various periods are statistically

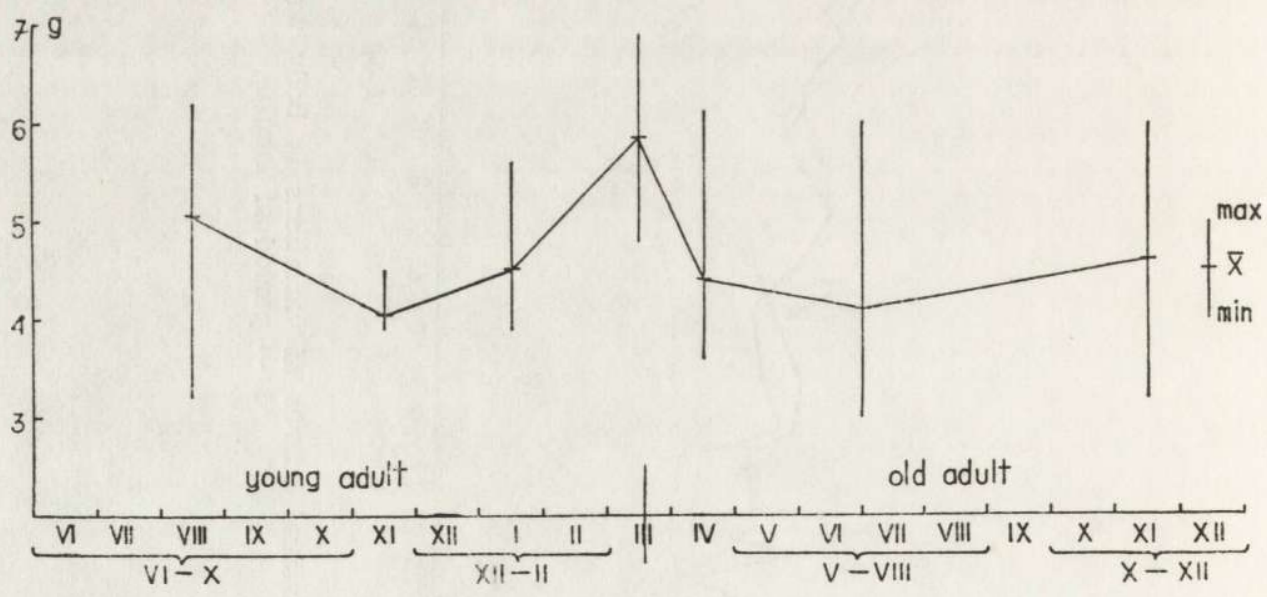

Fig. 4. Variations in absolute food intake (in grammes) in shrews during the experiment.

significant. Over the course of a year high food intake by old adults in March is very distinct (on an average $5.86 \mathrm{~g}$ per day) and also the considerable decrease in April (4.44 g) and during the period from May to August ( $4.09 \mathrm{~g}$ ). In winter (December-February) daily absolute food intake is higher in relation to November by only $0.45 \mathrm{~g}$ (Fig. 4).

The amount of food eaten during a day per gramme of body weight, expressed in percentages of body weight, varied from 4 to $136 \%{ }^{1}$ ). Out of the 1045 cases it was only in $22(2.1 \%)$ that absolute daily food intake exceeded the shrew's body weight and out of this number 8

$\left.{ }^{1}\right)$ It must be emphasised that these values were in general very high (up to $170 \%$ ) in shrews during the first days of the adaptation period. 
cases occurred in March, when the amount of food eaten was in general very high.

The caloric value of the food given to the shrews during the experiment was approx. $3.8 \mathrm{kcal} / \mathrm{g}$ of dry mass. The caloric value of meat eaten during a 24 -hour period was thus $11.55-26.56 \mathrm{kcal}$, on an average from $15.71 \mathrm{kcal}$ in November to $22.56 \mathrm{kcal}$ in March. Calculated per gramme of body (taking into consideration the mean body weight of shrews in the given 10-day period) this gives from 1.89 to $3.45 \mathrm{kcal} / \mathrm{g}$.

Analysis was made of the dependence of the amount of food consumed by shrews on the minimum temperature of their surroundings and the body weight of the animals. Examination of the connection between the mean daily amount of food consumed in a given 10-day period and the mean minimum temperature of a 10-day period during the course of the experiment, i.e. from November to October, revealed the existence of a significant correlation with a coefficient $r=-0.437$. Thus the lower the temperature, the greater the food consumption of the shrews. Correlating the mean minimum temperature of a 24 -hour period with the consumption of food over a 24-hour period by different shrews in each consecutive month however gave very few significant results (e.g. 4 out of 16 cases examined). A negative correlation was also found to exist between the mean body weight of shrews for a given 10-day period and the mean amount of food consumed over the year's experimental cycle, with $r=-0.585$, which is in agreement with the general rule.

As in the material examined three reciprocally interacting factors enter into consideration: temperature, amount of food consumed and body weight, calculation was made of partial correlation coefficients, eliminating the influence of the third character, for the two months chosen as examples: January and June. In January there was a weak negative partial correlation with a coefficient $r=-0.266$ between body weight and relative daily food intake with elimination of the influence of temperature. There is, however, no correlation between body weight and temperature and between temperature and food intake. In June there was found a negative correlation with a coefficient $r=-0.376$ (significant at 0.01 level) between relative daily food intake and minimum daily temperature with elimination of the influence of body weight. There is no correlation between the amount of food eaten and body weight and between body weight and minimum temperature for a 24-hour period.

\section{DISCUSSION}

The data obtained during these studies show that under conditions similar to natural ones, and when animals are supplied with food ad 
libitum, the phenomenon of seasonal variation in body occurred in shrews, although less distinctly than in nature. Weight loss during the period from August-October to January-February was $16.7 \%$, whereas in the case of free-living shrews during the same period this value was $24.4 \%$. Numerical data on the spring jump in growth are difficult to compare, since they do not take into consideration in the case of experimental animals the body weight of pregnant and nursing females, but in them also there is a distinct increase in body weight $(37.2 \%$ during the period from January-February to May-June, Fig. 1A and 2 , Table 3 and 4). It would follow from the above that the food factor alone does not in principle alter the course taken by Dehnel's phenomenon, but under laboratory conditions stabilized in respect of food and temperature the winter decrease in the body weight of shrews caught during the summer and autumn was not observed. These animals also failed to exhibit the spring jump in growth, although this was observed in individuals caught in the winter for keeping in the laboratory ( $\mathrm{P} \mathrm{u}$ ce $\mathrm{k}, 1964)$. Under natural conditions this evolutionally fixed reaction of shrews to the habitat conditions in which they live enables them to survive with reduced absolute food requirements ( $\mathrm{M} \mathrm{e} \mathrm{zh} \mathrm{zh}$ erin, 1964, 1965; Mezhzherin \& Melnikova, 1966; Myrcha, 1967) and reduced costs of their bioenergetics (G ę bc zyński, 1965).

The data obtained from captive animals kept under semi-natural conditions, in comparison with the earlier field and laboratory observations, suggest that the role of habitat factors, primarily temperature and length of day, is very important. They may significantly modify, and in extreme cases even inhibit the course of the seasonal depression in the shrew's body weight characteristic of free-living animals.

The sudden and distinct increase in daily food intake in March is striking. This phenomenon may be influenced by both intensification of the physiological processes in shrews in connection with the approaching reproductive season, and the complete removal of the straw mats covering the container during the period of particularly low temperature, and in consequence the sudden prolongation of the light phase.

It was found that during the winter period daily absolute food intake which on an average is $4.53 \mathrm{~g}$, is only $0.44(9.7 \%)$ higher than in summer $(4.09 \mathrm{~g})$. The increase in the amount of food per $1 \mathrm{~g}$ of body weight during the winter, of $62.1 \%$ in relation to $44.6 \%$ in summer, is thus attained chiefly owing to reduction in body weight (Table 4, Fig. 1B and 4).

The low food intake measured in weight, only in $2.1 \%$ of cases exceeding the body weight of the shrews, differs from the data given by 
many authors, in whose opinion it greatly exceeds $100 \%$ of body weight (Tupikova, 1949; Crowcroft, 1957; Hawkins \& Jewell, 1962; J u din, 1956, 1962; Mezhzherin, 1964, 1965). This is undoubtedly due to the fact that the meat was slightly dried and thus the caloric value of $1 \mathrm{~g}$ of food was higher. The caloric value of the natural food of shrews is low owing to the high water content, forming about $70 \%$ of their food ( $\mathrm{H} \mathrm{awkins} \& \mathrm{~J} \mathrm{ewe} 11,1962$ ). For instance the caloric value of the food eaten over a 24 -hour period by 4 shrews in $\mathrm{H}$ a w kins and Jewell's experiments (1962) was from 12.5 to 22.5 $\mathrm{kcal}$, and calculated per gramme of body weight: 1.80 to $2.30 \mathrm{kcal} / \mathrm{g}$ (the experiment was carried out in a laboratory at a temperature of $\left.14-16^{\circ} \mathrm{C}\right)$. The agreement between the shrews' daily caloric requirement in these authors' experiment with our own analogical data is striking 11.55 to $26.56 \mathrm{kcal}$. The mean values of the energy intake varied from $15.71 \mathrm{kcal}$ in November to $12.56 \mathrm{kcal}$ in March, that is, from 1.89 to $3.45 \mathrm{kcal} / \mathrm{g}$. The food used in $\mathrm{H}$ a w kin s \& $\mathrm{J}$ e w ell's studies (l.c.) was similar to the animals' natural food (Lumbricus sp., larvae of Tenebrio molitor and newborn mice), as indicated by the investigations of $\mathrm{Tu}$ pikova (1949), Mezhzherin (1961), J udin (1956, 1962 and Kisielewska (1963). The fact that according to $\mathrm{Hawkins} \& \mathrm{Je}$ we 11 (1962) the caloric value of Diptera larvae is $6.1 \mathrm{kcal} / \mathrm{g}$ deserves emphasis. The caloric value of the mixture of minced internal organs of a bullock forming the food of shrews in the present studies was approx. $3.8 \mathrm{kcal} / \mathrm{g}$ of dry mass, and was thus almost twice lower in caloric value.

The lack of correlation between the mean minimum temperature for 24-hour period and the daily food intake of different shrews in each consecutive calendar month forms some degree of confirmation of the statement made by Mezhzherin \& Melnikova (1966) that the daily relative food requirements of shrews in winter are characterized by considerable stability and do not depend on body weight, activity in searching for food or habitat temperature.

Acknowledgements: I would like to express my grateful thanks to Dr. Zdzisław Pucek, head of the Mammals Research Institute of the Polish Academy of Sciences, for his valued and kindly assistance in the elaboration of the above material.

\section{REFERENCES}

1. Coulianos C. C. \& Johnels A. G., 1962: Note on the subnivean environment of small mammals. Ark. Zool., 15, 24: 363-370. Göteborg-Uppsala.

2. Crowcroft P., 1957: The life of the shrew, 1-166. London.

3. Dehnel A., 1949: Badania nad rodzajem Sorex L. Annls Univ. M. Curie-Skłodowska, Sec. C, 4, 2: 17-102. Lublin. 
4. Gębczyński M., 1965: Seasonal and age changes of the metabolism and activity of Sorex araneus Linna e us, 1758. Acta theriol., 10, 22: 303-331.

5. H a w kins A. E. \& J e we 11 P. A., 1962: Food consumption and energy requirements of captive British shrews and the mole. Proc. zool. Soc. Lond., 138, 1: 137-155.

6. Judin B. S., 1956: Materialy po pitaniju burozubok (Sorex L.) Zapadnoj Sibiri. Tr. Tomsk. Gosud. Univ., 142: 295-302. Tomsk.

7. J u d in B. S., 1962: Ekologija burozubok (rod Sorex), Zapadnoj Sibiri. A. N. SSSR, Sibirskoe Otd. Tr. biol. in-ta, 8: 33-134.

8. Kisielewska K., 1963: Food composition and reproduction of Sorex araneus Linnaeus, 1758 in the light of parasitological research. Acta theriol., 7, 9: 127-153.

9. Mezhzherin V. A., 1961: Osobennosti ekologii burozubyh zemleroek (Soricinae) i dinamika ih čislennosti $\mathrm{v}$ lesostepi i polesí Ukrainy. Avtoref.: $1-15$, A.N. USSR, Inst. Zool., Kiev.

10. Mezhzherin V. A., 1964: Javlenie Denelja i ego vozmožnoe ob'jasnenie. Acta theriol., 8, 6: 95-114.

11. Mezhzherin V. A., 1965: Očerk četvertičnoj istorii i proishoždenija sovremennoj fauny zemleroek-burozubok (rod Sorex, Insectivora, Mammalia). Sb. „Mater. po četvert. periodu Ukrainy (k VII kongresu INQUA v SŠA)”: 164 173. Kiev.

12. Mezhzherin V. A. \& Melnikova T. L., 1966: Adaptivnoe značenie sezonnyh izmenenij nekotoryh morfo-fizjologičeskih pokazatelej zemleroek-burozubok (Sorex Linna e us, 1758). Acta theriol., 11, 25: 503-521.

13. Myrcha A., 1967: Comparative studies on the morphology of the stomach in the Insectivora. Acta theriol., 12, 14: 223-244.

14. Pucek Z., 1964: Morphological changes in shrews kept in captivity. Acta theriol., 8, 9: 137-166.

15. Pucek Z., 1965: Seasonal and age changes in the weight of internal organs of shrews. Acta theriol., 10, 26: 369-438.

16. Tupikova I. V., 1949: Pitanie i harakter sutočnoj aktivnosti zemleroek srednej polosy SSSR. Zool. Žurn., 28, 6: 561-572. Moskva.

Received, September 4, 1968.

Mammals Research Institute,

Polish Academy of Sciences,

Białowieża, Poland.

Elżbieta WOŁK

\section{CIEZŻAR CIAEA I DOBOWE POBRANIE POKARMU U RYJOWKI AKSAMITNEJ W NIEWOLI}

\section{Streszczenie}

W okresie od listopada 1966 do października 1967 badano sezonową zmienność ciężaru ciała i dobowego pobrania pokarmu u 36 ryjówek, Sorex araneus Lin$\mathrm{n}$ a e us, 1758, trzymanych indywidualnie w klatkach na wolnym powietrzu i obficie karmionych. W odróżnieniu od ryjówek trzymanych w warunkach laboratoryjnych, wystąpiło u zwierząt eksperymentalnych zjawisko zimowej depresji 
ciężaru ciała oraz wiosenny skok wzrostowy, w słabszym jednak stopniu niż w przyrodzie. Strata na ciężarze w okresie od sierpnia - października do stycznia lutego wynosiła 16,7\%, przyrost ciężaru ciała od stycznia - lutego do maja czerwca $-37,2 \%$ (Ryc. 1, 2, Tabela 3, 4). W warunkach eksperymentalnych brak było ciężarnych i karmiących samic.

Ciężar ciała podlegał znacznym wahaniom w krótkich odcinkach czasu, osiągając $w$ ciągu $2-20$ dni $8,9-43,6 \%$ wartości przed nagłym spadkiem lub wzrostem (Ryc. 3).

Minimalna względna ilość zjadanego $\mathrm{w}$ ciągu doby pokarmu (wyrażona $\mathrm{w}$ procentach ciężaru ciała) przypada $u$ młodych $w$ listopadzie, maksymalna w zimie, u przezimków minimalna latem, maksymalne w marcu (Ryc. 2, Tabela 4). Dobowe bezwzględne pobranie pokarmu w zimie jest tylko o $9,7 \%$ wyższe niż latem, różnica ta jest jednak istotna statystycznie (Ryc. 4, Tabela 4). Wzrost ilości pokarmu na gram ciała w okresie zimowym, wynoszącej $62,1 \%$ w porównaniu z 44,6\% latem jest głównie rezultatem zmniejszenia ciężaru ciała.

Występuje korelacja $(r=-0,437)$ między średnią minimalną temperaturą dekady a średnią dobową konsumpcją pokarmu, ale tylko w odniesieniu do wartości w przebiegu rocznym, brak jej natomiast przy rozpatrywaniu zmian z doby na dobę. Stwierdzono również korelację $(r=-0,585)$ między ciężarem ciała a ilością zjadanego pokarmu.

Dobowe pobranie pokarmu wahało się od 4 do $136 \%$ ciężaru ciała. Bezwzględne dobowe pobranie pokarmu wyrażone w gramach tylko w 22 na 1045 przypadków $(2,1 \%)$ przewyższało ciężar ciała ryjówki. Wartość kaloryczna mięsa zjadanego przez ryjówki w ciągu doby wynosiła średnio od 15,71 kcal w listopadzie do $22,56 \mathrm{kcal}$ w marcu, czyli $1,89-3,45 \mathrm{kcal} / \mathrm{g}$. 